\title{
Musculoskeletal pain in undergraduate health students: prevalence and associated factors*
}

\author{
Dor musculoesquelética em estudantes de graduação da \\ área da saúde: prevalência e fatores associados \\ Dolor musculoesquelético en estudiante de pregrado del \\ área sanitaria: prevalencia y factores asociados
}

How to cite this article:

Morais BX, Dalmolin GL, Andolhe R, Dullius AIS, Rocha LP. Musculoskeletal pain in undergraduate health students: prevalence and associated factors. Rev Esc Enferm USP. 2019;53:e03444. DOI: http://dx.doi.org/10.1590/S1980-220X2018014403444

\section{Bruna Xavier Morais ${ }^{1}$ \\ Graziele de Lima Dalmolin ${ }^{1}$ \\ Rafaela Andolhe ${ }^{1}$ \\ Angela Isabel dos Santos Dullius ${ }^{2}$ \\ Laurelize Pereira Rocha ${ }^{3}$}

* Extraído da dissertação: "Dor musculoesquelética e estresse em estudantes de graduação da área da saúde", Universidade Federal de Santa Maria, 2018.

${ }^{1}$ Universidade Federal de Santa Maria, Programa de Pós-Graduação em Enfermagem, Departamento de Enfermagem, Santa Maria, RS, Brazil.

${ }^{2}$ Universidade Federal de Santa

Maria, Programa de Pós-Graduação

em Enfermagem, Departamento de Estatística, Santa Maria, RS, Brazil.

${ }^{3}$ Universidade Federal do Rio Grande, Programa de Pós-Graduação em Enfermagem, Departamento de Enfermagem, Rio Grande, RS, Brazil.

\begin{abstract}
Objective: To assess the prevalence and factors associated with musculoskeletal pain in undergraduate health students. Method: A cross-sectional study was conducted with undergraduate students from a university in the south of Brazil between April and July 2017. The Brazilian version of the Standardized Nordic Questionnaire and a questionnaire for the characterization of students were used. Descriptive statistics, the chi-square test and Poisson regression were used for the analysis. Results: Participation of 792 undergraduate health students. The region of the vertebral column had a higher prevalence $(74.9 \%)$ of musculoskeletal pain. The variables of female sex, age between 18 and 20 years, overweight, not having time for leisure, six or more daily hours of mobile phone use, having a clinical condition with medical diagnosis and attending the intermediate or final semesters of the course were associated with musculoskeletal pain. Conclusion: The high prevalence of musculoskeletal pain demonstrates the need for strategies aimed at preventing this aggravation still in the academic setting.
\end{abstract}

\section{DESCRIPTORS}

Students, Health Occupations; Musculoskeletal Pain; Cumulative Trauma Disorders; Occupational Health.
Corresponding author: Bruna Xavier Morais Universidade Federal de Santa Maria,

Centro de Ciências da Saúde Av. Roraima, 1000, Prédio 26 CEP 97105-900 - Santa Maria, RS, Brazil bruna_morais100@hotmail.com
Received: 04/14/2018 Approved: 09/13/2018 


\section{INTRODUCTION}

According to data from the Brazilian Institute of Geography and Statistics, about 27 million Brazilians aged 18 or over are affected by musculoskeletal pain (MSP) in the region of the spine ${ }^{(1)}$. MSP is a consequence of repetitive exertion, excessive use of the musculoskeletal system, and work-related musculoskeletal disorders ${ }^{(2)}$.

MSP is becoming increasingly frequent in the work and academic environment and is related to both professional activities and life habits adopted by individuals ${ }^{(3)}$. In the work environment, people working in public health institutions, and exposed to physical, psychic and environmental factors have a prevalence of MSP of between $65.7 \%$ and $92.1 \%(4-5)$.

Just as health workers, undergraduate health students are also exposed to physical and psychic factors, both in the academic scenario and in their insertion in the work environment, which can trigger the occurrence of MSP. High prevalence rates of MSP are described in the international (67.1\%) and Brazilian (87\%) literature among health students ${ }^{(6-7)}$.

In their academic routine, health students remain seated for long periods, often in inadequate furniture, develop a large amount of curricular activities and carry heavy materials, which can lead to musculoskeletal overload ${ }^{(8)}$. In addition, they spend time in health institutions for attending practical classes and internship programs. They perform professional activities of the corresponding position, which often must be done fast, and this leads to the adoption of inappropriate postures, besides the movement repetitiveness ${ }^{(9)}$.

Students also use notebooks and mobile phones frequently as support for academic activities, and in their leisure time. When using these electronic devices, they often adopt inadequate postures that can cause pain and musculoskeletal changes, especially in the upper limbs and spine ${ }^{(10)}$.

This is a worrying context, since students of the health area are inside an environment that favors the exposure to risk factors for the occurrence of MSP, and the symptoms may interfere with the well-being and quality of life of these future professionals.

A search was performed in the databases of the Latin American and Caribbean Literature in Health Sciences (LILACS), SciVerse Scopus (SCOPUS) and Medline (via US National Library of Medicine) in January 2018 with the objective to identify scientific evidence of MSP in undergraduate health students over the previous five years (2013-2017). Ten studies addressing MSP in undergraduate health students were available online. Of these, four addressed Dentistry students; two, Medical students; two, Nursing students; and two, students of Biological Sciences and Health. The lack of studies including Speech-Language Pathology and Occupational Therapy courses was evident, as well as of studies relating leisure activities and the backpack weight with the occurrence of MSP among undergraduate health students.

In view of the above, the research question of this study was 'What is the prevalence and factors associated with
MSP in undergraduate health students?'. The aim was to assess the prevalence and factors associated with MSP in undergraduate health students.

\section{METHOD}

\section{TyPe OF STUDY}

Cross-sectional study.

\section{Population}

The study was conducted with undergraduate health students of a public university in the south of Brazil. During the period of study, the population was composed of 2,334 students divided into seven courses, namely Nursing, Pharmacy, Physiotherapy, Speech-language Pathology, Medicine, Occupational Therapy and Dentistry.

\section{SeleCtION CRITERIA}

Inclusion criteria were age over 18 years old, and to be enrolled and regularly attending the course. Students in leave of absence for any reason during the data collection period were excluded.

\section{SAMPLE DEFINITION}

In the development of the study, for sample calculation, was considered a $95 \%$ confidence interval, sample error of 0.3 units, standard deviation of 3.08 points ${ }^{(3)}$, total population of 2,334 and the minimum sample of 346 students. For possible losses, was added $20 \%$ and the final sample was of 416 participants. Probabilistic sampling by conglomerate was the sample selection method, thus, the semesters of courses were divided into beginning, middle and end.

\section{DATA COLLECTION}

Data collection was performed by the study authors and previously trained members of the research group between April and July, 2017. Collection was performed during classes in sessions scheduled with teachers responsible for the discipline, and online with students of the last semesters, since they were only doing internships. The Brazilian version of the Standardized Nordic Questionnaire ${ }^{(11-12)}$ was applied, as well as a self-administered instrument that included sociodemographic questions (sex, age, marital status), habits and health questions (weight, height, use of alcoholic beverage and tobacco, physical activity, leisure time, daily time of mobile phone use, medical diagnosis), and academic questions (course, semester, academic scholarship, voluntary internships, practical classes, daily time of computer use and weight of the bag/backpack).

The Standardized Nordic Questionnaire is used to check reports of MSP in ten regions through three questions: Have you at any time during the last 12 months had any pain or discomfort in ...? Has this problem prevented you from doing something at home or away from home in the last year? Have you had this pain/ discomfort during the last seven days? There were two 
options of answer, yes or no. In order to avoid possible memory bias, in this study, we considered the presence of musculoskeletal symptoms in the last seven days prior to data collection.

The weight of students and their bags/backpacks was measured through $\mathrm{G}$-tech scales in kilograms $(\mathrm{kg})$, and these were compared and calibrated by weighing an object of known weight. Students who answered the online survey instrument self-reported their information.

Anatomical regions were divided into vertebral column (cervical, thoracic and lumbar), upper limbs (shoulder, elbow and wrist or hand) and lower limbs (thighs, knees, legs and ankles). The presence of MSP in each region was evaluated through students' complaints in at least one of the subregions described.

\section{ANALYSIS AND PROCESSING OF DATA}

Data were inserted in a Microsoft Excel spreadsheet with double independent typing. After checking typing errors and inconsistencies, data were analyzed in the PASW Statistics (Predictive Analytics Software, SPSS Inc., Chicago - USA) version 18.0 for Windows.

The descriptive statistical analysis of sociodemographic, habits and health and academic variables was performed. Normality of data was assessed by the Kolmogorov-Smirnov test. For the analysis of associations of independent variables with MSP, were used the chi-square or Fisher's exact tests when appropriate and was considered a 95\% confidence interval with statistical significance level of $\mathrm{p}<0.05$.

The MSP was analyzed dichotomically (present or absent) in each anatomical region and presented as absolute and relative frequencies. For the calculation of Body Mass Index (BMI), was used the weight/height ${ }^{2}$ formula, and values were classified according to international standards for adults, as proposed by the World Health Organization $^{(13)}$.

The Poisson regression (stepwise method) with robust and adjusted variance was used to check the variables associated with MSP regions. Prevalence ratios (PR) and confidence intervals $(95 \% \mathrm{CI})$ were estimated. Independent variables potentially associated with MSP with $p \leq 0.05$ were included in the analyzes. The associations of variables to the outcome of $\mathrm{p}<0.05$ were considered statistically significant.

\section{ETHICAL ASPECTS}

The study was approved by the Research Ethics Committee of the institution in January 2017 for Ethical Appraisal under Certificate of Presentation number 63473317.1.0000.5346 and Opinion number 1,888,749. Ethical aspects determined in Resolution 466/12 of the National Council were respected. Students were informed about the study and signed two copies of the Informed Consent form (one for students and the other for the researcher).

\section{RESULTS}

The study included 792 undergraduate health students, of which 44 participated online. There was a predominance of female (74.6\%), single (94.6\%) students with median age of 21 years (19-23).

Regarding students' habits, the majority reported occasional consumption of alcoholic beverages (63.1\%), no use of tobacco (88.6\%), physical activity practice $(35.9 \%)$ and having time for leisure occasionally (55.4\%). Students' median time of mobile phone use was five daily hours (3-10), and of the computer was two daily hours (1-4). The median weight of the backpack was $3.1 \mathrm{~kg}(2.5-4)$, and the most used means of transportation to go to university was the bus $(52.1 \%)$.

As for health, $71.1 \%$ of students stated not having any medical diagnosis and $59.8 \%$ did not use medication. In those with a medical diagnosis, respiratory diseases (35.5\%) and mental and behavioral disorders $(21.5 \%)$ predominated. Regarding BMI, $67 \%$ of students were classified as normal weight.

In relation to academic characteristics, most students were attending between the $3^{\text {rd }}$ and $6^{\text {th }}$ semesters $(41.3 \%)$, did not have an academic scholarship (72.2\%), did not perform voluntary internships $(83.2 \%)$ and attended practical classes (88.5\%).

The highest prevalence of MSP in the last seven days among undergraduate health students was in the vertebral column (74.9\%), particularly in the cervical region $(51.0 \%)$, and lumbar region (54.5\%), followed by upper limbs (54.1\%), particularly the shoulders (40.4\%), and lower limbs (43.6\%), especially the legs (26.4\%).

Table 1 presents the prevalence, and crude and adjusted associations between MSP in the column region and variables that presented $\mathrm{p} \leq 0.05$.

After adjusted analysis, the prevalence of MSP was higher among the female sex (6\%), age between 18 and 20 years $(21 \%)$ and 24 to 26 years $(21 \%)$, lack of leisure time (14\%) six or more daily hours of mobile phone use (3\%), attending the last semesters of courses (5\%), and backpack weight of $3.2 \mathrm{~kg}$ or more $(6 \%)$.

Table 2 presents the prevalence, and crude and adjusted associations between musculoskeletal pain in the upper limbs region and variables that presented $\mathrm{p} \leq 0.05$.

After adjusted analysis, the prevalence of MSP was higher among those with a medical diagnosis (7\%), without leisure time (15\%) and with six daily hours or more of mobile phone use (6\%).

Table 3 shows the prevalence and crude and adjusted associations between MSP in the lower limbs region and variables with $\mathrm{p} \leq 0.05$.

After adjusted analysis, the following variables showed a higher prevalence of MSP: having a medical diagnosis (9\%), being overweight (8\%), lack of leisure time (11\%) and using the mobile phone for six daily hours or more $(6 \%)$. 
Table 1 - Prevalence, crude and adjusted analysis of the association of musculoskeletal pain in the vertebral column with sociodemographic, habits and health, and academic variables of undergraduate health students - Rio Grande do Sul, Brazil, 2017.

\begin{tabular}{|c|c|c|c|c|c|c|c|}
\hline \multirow{2}{*}{ Variable } & \multicolumn{3}{|c|}{ Vertebral column pain } & \multicolumn{2}{|c|}{ Crude analysis } & \multicolumn{2}{|c|}{ Adjusted analysis** } \\
\hline & $\mathbf{n}$ & $\%$ & $\mathrm{p}^{*}$ & CPR $(95 \% \mathrm{Cl})$ & $\mathbf{p}$ & APR $(95 \% \mathrm{Cl})$ & $\mathbf{P}$ \\
\hline \multicolumn{8}{|l|}{ Sex } \\
\hline Female & 459 & 77.7 & 0,002 & $1.066(1.021-1.113)$ & 0.004 & $1.060(1.015-1.108)$ & 0.009 \\
\hline Male & 134 & 66.7 & & 1 & & 1 & \\
\hline \multicolumn{8}{|l|}{ Age } \\
\hline 18 to 20 years & 256 & 76.6 & \multirow{5}{*}{0.001} & $1.226(1.089-1.380)$ & 0.001 & $1.211(1.073-1.367)$ & 0.002 \\
\hline 21 to 23 years & 218 & 76.2 & & $1.223(1.085-1.377)$ & 0.001 & $1.208(1.070-1.364)$ & 0.002 \\
\hline 24 to 26 years & 74 & 76.3 & & $1.223(1.079-1.387)$ & 0.002 & $1.215(1.070-1.380)$ & 0.003 \\
\hline 27 to 29 years & 20 & 74.1 & & $1.208(1.040-1.403)$ & 0.013 & $1.190(1.024-1.383)$ & 0.023 \\
\hline 30 years or more & 15 & 44.1 & & 1 & & 1 & \\
\hline \multicolumn{8}{|l|}{ Time for leisure } \\
\hline No & 58 & 86.6 & \multirow{3}{*}{0.000} & $1.143(1.081-1.208)$ & 0.000 & $1.140(1.079-1.205)$ & 0.000 \\
\hline Sometimes & 354 & 80.6 & & $1.106(1.063-1.151)$ & 0.000 & $1.101(1.058-1.146)$ & 0.000 \\
\hline Yes & 181 & 63.3 & & 1 & & 1 & \\
\hline \multicolumn{8}{|c|}{ Daily time of mobile phone use } \\
\hline 6 hours or more & 293 & 79 & 0.013 & $1.045(1.010-1.081)$ & 0.012 & $1.039(1.005-1.075)$ & 0.000 \\
\hline Up to 5 hours & 298 & 71.3 & & 1 & & 1 & \\
\hline \multicolumn{8}{|l|}{ Semester } \\
\hline End ( $7^{\text {th }}$ to $\left.12^{\text {th }}\right)$ & 150 & 80.6 & \multirow{3}{*}{0.003} & $1.075(1.028-1.125)$ & 0.002 & $1.059(1.007-1.112)$ & 0.025 \\
\hline Middle ( $3^{\text {rd }}$ to $\left.6^{\text {th }}\right)$ & 254 & 77.7 & & $1.058(1.015-1.102)$ & 0.008 & $1.048(1.003-1.096)$ & 0.036 \\
\hline Beginning $\left(1^{\text {st }}\right.$ and $\left.2^{\text {nd }}\right)$ & 189 & 68 & & 1 & & 1 & \\
\hline \multicolumn{8}{|l|}{ Academic scholarship } \\
\hline Yes & 179 & 81.4 & 0.009 & $1.052(1.015-1.090)$ & 0.005 & $1.031(0.993-1.071)$ & 0.115 \\
\hline No & 414 & 72.4 & & 1 & & 1 & \\
\hline \multicolumn{8}{|l|}{ Voluntary internship } \\
\hline Yes & 109 & 82 & 0.039 & $1.049(1.007-1.093)$ & 0.022 & $1.030(0.988-1.074)$ & 0.167 \\
\hline No & 484 & 73.4 & & 1 & & 1 & \\
\hline \multicolumn{8}{|l|}{ Backpack weight } \\
\hline $3.2 \mathrm{~kg}$ or more & 315 & 79.9 & 0.001 & $1.058(1.023-1.095)$ & 0.001 & $1.061(1.025-1.098)$ & 0.001 \\
\hline Up to $3.1 \mathrm{~kg}$ & 278 & 70 & & 1 & & 1 & \\
\hline
\end{tabular}

Table 2 - Prevalence, crude and adjusted analysis of the association of musculoskeletal pain in the upper limbs with sociodemographic, habits and health, and academic variables of undergraduate health students - Rio Grande do Sul, Brazil, 2017.

\begin{tabular}{|c|c|c|c|c|c|c|c|}
\hline \multirow{2}{*}{ Variable } & \multicolumn{3}{|c|}{ Upper limbs pain } & \multicolumn{2}{|c|}{ Crude analysis } & \multicolumn{2}{|c|}{ Adjusted analysis** } \\
\hline & $\mathrm{N}$ & $\%$ & $\mathrm{p}^{*}$ & CPR $(95 \% \mathrm{Cl})$ & $p$ & APR $(95 \% \mathrm{Cl})$ & $p$ \\
\hline \multicolumn{8}{|l|}{ Sex } \\
\hline Female & 343 & 58 & 0,000 & $1.111(1.052-1.173)$ & 0.000 & & \\
\hline Male & 85 & 42.3 & & 1 & & & \\
\hline \multicolumn{8}{|l|}{ Medical diagnosis } \\
\hline Yes & 142 & 62 & 0.004 & $1.074(1.025-1.127)$ & 0.003 & $1.071(1.022-1.122)$ & 0.004 \\
\hline No & 286 & 50.8 & & 1 & & 1 & \\
\hline \multicolumn{8}{|l|}{ Time for leisure } \\
\hline No & 48 & 71.6 & 0000 & $1.177(1.093-1.268)$ & 0.000 & $1.158(1.073-1.249)$ & 0.000 \\
\hline Sometimes & 249 & 56.7 & 0.000 & $1.075(1.023-1.129)$ & 0.004 & $1.061(1.010-1.116)$ & 0.019 \\
\hline Yes & 131 & 45.8 & & 1 & & 1 & \\
\hline \multicolumn{8}{|l|}{ Physical activity } \\
\hline No & 291 & 57.3 & 0.014 & $1.061(1.011-1.113)$ & 0.015 & $1.035(0.987-1.086)$ & 0.159 \\
\hline Yes & 137 & 48.2 & & 1 & & 1 & \\
\hline \multicolumn{8}{|c|}{ Daily time of mobile phone use } \\
\hline 6 hours or more & 221 & 59.6 & 0.003 & $1.071(1.024-1.120)$ & 0.003 & $1.065(1.019-1.114)$ & 0.005 \\
\hline Up to 5 hours & 205 & 49 & & 1 & & 1 & \\
\hline \multicolumn{8}{|l|}{ Backpack weight } \\
\hline $3.2 \mathrm{~kg}$ or more & 229 & 58.1 & 0.024 & $1.053(1.007-1.102)$ & 0.024 & & \\
\hline Up to $3.1 \mathrm{~kg}$ & 199 & 50.1 & & 1 & & & \\
\hline
\end{tabular}

Legend: CPR (crude prevalence ratio); APR (adjusted prevalence ratio); CI (confidence interval); ${ }^{*}$ Chi-square test; **Habits and health data (medical diagnosis + leisure + physical activity + daily time of mobile phone use). 
Table 3 - Prevalence, crude and adjusted analysis of the association of musculoskeletal pain in the lower limbs with sociodemographic, habits and health and academic variables of undergraduate health students - Rio Grande do Sul, Brazil, 2017.

\begin{tabular}{|c|c|c|c|c|c|c|c|}
\hline \multirow{2}{*}{ Variable } & \multicolumn{3}{|c|}{ Lower limbs pain } & \multicolumn{2}{|c|}{ Crude analysis } & \multicolumn{2}{|c|}{ Adjusted analysis** } \\
\hline & $\mathbf{n}$ & $\%$ & $\mathrm{p}^{*}$ & CPR $(95 \% \mathrm{CI})$ & $p$ & APR (95\% CI) & p \\
\hline \multicolumn{8}{|l|}{ Sex } \\
\hline Female & 270 & 45.7 & 0.039 & $1.061(1.003-1.122)$ & 0.038 & $1.048(0.991-1.109)$ & 0.103 \\
\hline Male & 75 & 37.3 & & 1 & & 1 & \\
\hline \multicolumn{8}{|l|}{ Age } \\
\hline 18 to 20 years & 159 & 47.6 & \multirow{5}{*}{0.022} & $1.141(1.008-1.291)$ & 0.037 & $1.130(0.998-1.279)$ & 0.055 \\
\hline 21 to 23 years & 128 & 44.8 & & $1.119(0.987-1.267)$ & 0.079 & $1.108(0.977-1.256)$ & 0.109 \\
\hline 24 to 26 years & 30 & 30.9 & & $1.012(0.882-1.161)$ & 0.868 & $1.006(0.877-1.155)$ & 0.927 \\
\hline 27 to 29 years & 12 & 44.4 & & $1.116(0.936-1.330)$ & 0.220 & $1.103(0.926-1.314)$ & 0.273 \\
\hline 30 or more & 10 & 29.4 & & 1 & & 1 & \\
\hline \multicolumn{8}{|l|}{ Medical diagnosis } \\
\hline Yes & 123 & 53.7 & \multirow[t]{2}{*}{0.000} & $1.102(1.048-1.160)$ & 0.000 & $1.099(1.045-1.156)$ & 0.000 \\
\hline No & 222 & 39.4 & & 1 & & 1 & \\
\hline \multicolumn{8}{|l|}{ IMC } \\
\hline Overweight & 82 & 53.2 & \multirow{4}{*}{0.050} & $1.089(1.027-1.156)$ & 0.005 & $1.081(1.020-1.146)$ & 0.009 \\
\hline Obesity & 28 & 45.9 & & $1.037(0.947-1.136)$ & 0.431 & $1.043(0.954-1.141)$ & 0.354 \\
\hline Low weight & 19 & 42.2 & & $1.011(0.910-1.124)$ & 0.840 & $1.018(0.915-1.132)$ & 0.741 \\
\hline Normal weight & 216 & 40.7 & & 1 & & 1 & \\
\hline \multicolumn{8}{|l|}{ Tobacco use } \\
\hline Yes & 7 & 63.6 & \multirow{3}{*}{0.041} & $1.151(0.966-1.372)$ & 0.116 & & \\
\hline Sometimes & 39 & 51.3 & & $1.064(0.984-1.151)$ & 0.120 & & \\
\hline No & 296 & 42.2 & & 1 & & & \\
\hline \multicolumn{8}{|l|}{ Time for leisure } \\
\hline No & 39 & 58.2 & \multirow{3}{*}{0.020} & $1.134(1.042-1.235)$ & 0.004 & $1.116(1.028-1.212)$ & 0.009 \\
\hline Sometimes & 193 & 44 & & $1.032(0.980-1.087)$ & 0.235 & $1.025(0.974-1.079)$ & 0.339 \\
\hline Yes & 113 & 39.5 & & 1 & & 1 & \\
\hline \multicolumn{8}{|c|}{ Daily time of mobile phone use } \\
\hline 6 hours or more & 180 & 48.5 & 0.007 & $1.069(1.018-1.121)$ & 0.007 & $1.068(1.018-1.119)$ & 0.007 \\
\hline Up to 5 hours & 163 & 39 & & 1 & & 1 & \\
\hline \multicolumn{8}{|l|}{ Course } \\
\hline Nursing & 70 & 59.8 & \multirow{7}{*}{0.000} & $1.222(1.128-1.324)$ & 0.000 & & \\
\hline Speech-language Pathology & 36 & 57.1 & & $1.202(1.091-1.324)$ & 0.000 & & \\
\hline Occupational Therapy & 54 & 52.9 & & $1.170(1.073-1.274)$ & 0.000 & & \\
\hline Physiotherapy & 31 & 44.3 & & $1.103(0.999-1.218)$ & 0.052 & & \\
\hline Medicine & 72 & 37.5 & & $1.051(0.974-1.135)$ & 0.197 & & \\
\hline Pharmacy & 38 & 36.2 & & $1.041(0.953-1.138)$ & 0.370 & & \\
\hline Dentistry & 44 & 30.8 & & 1 & & & \\
\hline
\end{tabular}

Legend: CPR (crude prevalence ratio); APR (adjusted prevalence ratio); CI (confidence interval); ${ }^{*}$ Chi-square test; **Sociodemographic data (sex + age); habits and health (medical diagnosis + BMI + leisure + daily use of mobile phone).

\section{DISCUSSION}

The undergraduate health students investigated had high percentages of MSP in the previous seven days, especially in the vertebral column region. This finding was similar to that found in the state of Pernambuco with university students. Their MSP was evaluated in the previous seven days (76.5\%), and the region of the vertebral column (cervical, thoracic and lumbar) was the one with the highest intensity of pain ${ }^{(14)}$.

In the academic environment, students remain in classrooms for long periods, sometimes sitting on furniture unsuitable for their stature. As a result, they may remain in inadequate ergonomic positions, which triggers musculoskeletal changes ${ }^{(3)}$. Furthermore, students perform activities of their future profession in health services where they sometimes manipulate weights, often move in search of materials, and adopt static postures and repetitive movements that may favor the development of MSP $^{(9)}$.

Women presented a prevalence up to six times higher for the occurrence of MSP compared to men. This can happen particularly because of their differences of muscle, bone mass and height, and more fragile joints, when compared to $\operatorname{men}^{(14)}$.

Students with a medical diagnosis had higher prevalence of MSP in the upper and lower limbs. Diseases of the respiratory system and mental and behavioral disorders were among the most reported diagnoses by students. In relation 
to respiratory system diseases, the reduced oxygen supply to tissues influences the consumption of energy used for muscle contraction and relaxation, which can cause muscular fatigue ${ }^{(15)}$ and contribute to the increase of MSP in the extremities, as observed in the results.

Furthermore, mental and behavioral disorders, especially prolonged stress, may be associated with the occurrence of painful conditions, as these can suppress the immune system and result in tissue damage ${ }^{(16)}$. The 'somatization' process, that is, physical symptoms resulting from psychological conditions, can often cause muscular tension in individuals and, consequently, result in $\mathrm{MSP}^{(17)}$.

Not having time or only sometimes having time for leisure had prevalence up to $15 \%$ higher on the development of MSP. Although the data collection period was between the middle and the end of the semester, when students had great academic task demands, sparing some amount of time for leisure activities in the routine is key for students' well-being. In these moments, they temporarily detach themselves from academic environment demands, and this helps with the relief of everyday life tensions ${ }^{(18-19)}$.

Students classified as overweight had 8\% higher prevalence of MSP in the lower limbs. Excess weight may be related to various effects on individuals' bones and joints, such as bone demineralization, dysfunction and deformity, and $\mathrm{MSP}^{(20)}$. Overweight and obesity are also associated with chronic diseases, which are divided into inflammatory or degenerative diseases of the musculoskeletal system ${ }^{(21)}$.

Students with six or more daily hours of mobile phone use also had higher prevalence of MSP compared to students with up to five daily hours of mobile phone use. Mobile phones are increasingly being used as a form of leisure, and as a tool that assists academic demands. However, excessive use of these devices is associated with the occurrence of tendinitis in the hand and elbow, manifested by tendon inflammation that causes pain and loss of strength, mainly due to repetitive movements. Likewise, the adoption of inappropriate postures and muscle overload are related to the occurrence of pain in the cervical and lumbar regions ${ }^{(22)}$.

The use of bags or backpacks weighing $3.2 \mathrm{~kg}$ or more was a factor associated with the occurrence of MSP in two anatomical regions. Students often do not use the backpacks in a suitable ergonomic way, which overloads the musculoskeletal structures and favors the development of pain. For example, the use of handbags or backpacks with a strap on only one shoulder can modify the anatomical plane, cause musculoskeletal imbalance and, consequently, requires greater effort of this system to correct deviations due to the inadequate transport of material ${ }^{(23)}$.

The researched institution offers lockers for Dentistry students, so they can keep their clinical practice material, and avoid the daily transportation between the institution and home. This is a good strategy to prevent musculoskeletal symptoms among students, since they use a large amount of material for clinical care, and is apparently in line with the presented results of a lower prevalence of MSP among these students.

Nursing, Speech-language Pathology, and Occupational Therapy students presented higher prevalence of MSP compared to students from other courses. Nursing and Occupational Therapy students perform their activities both in hospital care and in basic care by promoting the care and rehabilitation of patients. When performing these activities, they can handle weights and adopt static and non-ergonomic postures, which can cause muscle overload ${ }^{(9)}$. Speechlanguage Pathology students sometimes had different timetables, and some classes were held outside the institution campus. In some cases, their internship programs were held during the day and in the afternoon they had classes, which resulted in a great daily demand, both care and academic.

Students of intermediate and final semesters had higher prevalence of vertebral column pain compared to students of initial semesters. This may be related to students' greater clinical or care practice during these semesters. A similar result was found in a study conducted in the state of Pernambuco, where the frequency of pain in the cervical region increased as the semesters of the Dentistry course advanced $(\mathrm{p}<0.002)^{(24)}$.

Some subjective aspects of students of these semesters may be related to the occurrence of MSP, for example, feelings of unpreparedness, insecurity and fear of unemployment that may interfere in students' physical health. Intermediate and final semesters coincide with a high demand for activities, such as exams, reports and final papers, as well as students' insertion in the labor market. In this scenario, they perform activities of their future profession that require a professional, ethical and responsible attitude. In developing these activities, students can sometimes remain in the standing position for a long time. This can cause isometric muscle contractions as a result of reduced blood circulation and prolonged contraction that causes accumulation of metabolic waste in muscles and results in worsening of musculoskeletal symptoms ${ }^{(7,25)}$.

The cross-sectional design is a limitation of the study, since it does not allow to infer causality. The access to students of the last semester was also difficult because of their high demand of internships, often in places far from the university. This fact explains the choice for the online questionnaire. Since the number of online participants was small by considering the sample size, the issues of backpack weight and body weight, which were self-reported, did not have representative interference in the study results. The memory bias may have been minimized because the reports of MSP were from the previous seven days.

Investigating and knowing the variables interfering in students' physical health is important for the development of strategies for promoting health and well-being in the academic environment that can also help in the teachinglearning process. Although the study was developed in the southern region of the country, the findings can serve as a basis for other Brazilian contexts by considering the representative sample of participants in the study.

\section{CONCLUSION}

A high percentage of MSP was found among undergraduate health students. The study showed that different factors had a significant association with MSP, namely: sociodemographic (female sex and age between 18 and 20 
years); habits and health (overweight, not having time for leisure, six or more daily hours of mobile phone use and having a medical diagnosis); and academic (intermediate or final semesters of the course). These factors had higher prevalence for the occurrence of MSP in the investigated regions compared to the other studied groups.

Thus, the results showed that the association of important factors collaborated with MSP among health students, and confirmed its multifactorial nature. Another conclusion was the relevance of this symptomatology among students in the academic context, since it can interfere negatively in the health and teaching-learning process of this population.

The development of studies for the health promotion of students still in the academic setting is recommended, since this is where their professional lives begin.

\section{RESUMO}

Objetivo: Verificar a prevalência e fatores associados à dor musculoesquelética em estudantes de graduação da área da saúde. Método: Estudo transversal, realizado com estudantes de graduação de uma universidade do Sul do Brasil no período de abril a julho de 2017. Utilizou-se do questionário de caracterização dos estudantes e da versão brasileira do Standardized Nordic Questionnaire. Para a análise, foram empregados estatística descritiva, teste do qui-quadrado e regressão de Poisson. Resultados: Participaram do estudo 792 estudantes de graduação da área da saúde. A região da coluna vertebral apresentou maior prevalência (74,9\%) de dor musculoesquelética. As variáveis sexo feminino, idade entre 18 e 20 anos, sobrepeso, não ter tempo para o lazer, utilizar 6 ou mais horas diárias o celular, possuir condição clínica com diagnóstico médico e estar nos semestres intermediários ou finais do curso apresentaram-se associadas à ocorrência de dor musculoesquelética. Conclusão: Devido à elevada prevalência de dor musculoesquelética, destaca-se a necessidade da adoção de estratégias que visem à prevenção desse agravo ainda na academia.

\section{DESCRITORES}

Estudantes de Ciências da Saúde; Dor Musculoesquelética; Transtornos Traumáticos Cumulativos; Saúde do Trabalhador.

\section{RESUMEN}

Objetivo: Verificar la prevalencia y factores asociados con el dolor musculoesquelético en estudiantes de pregrado del área sanitaria. Método: Estudio transversal, realizado en con estudiantes de pregrado de una universidad del Sur de Brasil en el período de abril a julio de 2017. Se empleó el cuestionario de caracterización de los estudiantes y la versión brasileña del Standardized Nordic Questionnaire. Para el análisis, se emplearon estadística descriptiva, prueba del Chi cuadrado y regresión de Poisson. Resultados: Participaron en el estudio 792 estudiantes de pregrado del área sanitaria. La región de la columna vertebral presentó mayor prevalencia (74,9\%) de dolor musculoesquelético. Las variables sexo femenino, edad entre 18 y 20 años, sobrepeso, no tener tiempo para el ocio, utilizar el teléfono móvil seis o más horas diarias, tener condición clínica con diagnóstico médico y estar en los semestres intermedios o finales del curso se presentaron asociados con la ocurrencia de dolor musculoesquelético. Conclusión: En virtud de la elevada prevalencia de dolor musculoesquelético, se destaca la necesidad de la adopción de estrategias que tengan el objetivo de prevenir ese agravamiento aún en el gimnasio.

\section{DESCRIPTORES}

Estudiantes del Área de la Salud; Dolor Musculoesquelético; Trastornos de Traumas Acumulados; Salud Laboral.

\section{REFERENCES}

1. Instituto Brasileiro de Geografia e Estatística. Percepção do estado de saúde, estilos de vida e doenças crônicas: Brasil, grandes regiões e unidades de federação [Internet]. Rio de Janeiro: IBGE; 2013 [citado 2018 abr. 12]. Disponível em: ftp://ftp.ibge.gov.br/PNS/2013/ pns2013.pdf

2. Sociedade Brasileira de Estudo para Dor. Dor Musculoesquelética [Internet]. São Paulo: SBED; 2009 [citado 2018 mar. 18]. Disponível em: http://www.sbed.org.br/sites/arquivos/downloads/fasc_dor_musculoesqueletica.pdf

3. Gomes Neto M, Sampaio GS, Santos PS. Frequência e fatores associados a doresmusculoesqueléticas em estudantes universitários. Rev Pesq Fisioter [Internet]. 2016 [citado 2018 mar. 18];6(1):26-34. Disponível em: https://www5.bahiana.edu.br/index.php/fisioterapia/article/ view/790/566

4. Lima JP, Sousa AP, Santos EVL, Bezerra ALD, Sousa MNA. Prevalência de distúrbios osteomioarticulares e algias em fisioterapeutas. Rev Saúde Pública Santa Catarina 2015;8(3):98-108.

5. Garbin AJl, Garbin CAS, Arcieri RM, Rovida TAS, Freire ACGF. Musculoskeletal pain and ergonomic aspects of dentistry. Rev Dor [Internet] 2015 [cited 2018 Mar 19];16(2):90-5. Available from: http://www.scielo.br/pdf/rdor/v16n2/1806-0013-rdor-16-02-0090.pdf

6. Almhdawi KA, Mathiowetz V, Al-Hourani Z, Khader Y, Kanaan SF, Alhasan M. Musculoskeletal pain symptoms among allied health professions' students: prevalence rates and associated factors. J Back Musculoskelet Rehabil. 2017;30(6):1291-1301.

7. Mascarenhas CHM, Novaes SV. Sintomas osteomusculares em acadêmicos dos cursos de saúde de uma universidade pública. Rev Ciênc Desenvol. 2015;8(1):113-31.

8. Caromano FA, Amorim CAP, Rebelo CF, Contesini AM, Fávero FM, Frutuoso JRC, et al. Prolonged sitting and physical discomfort in university students. Acta Fisiatr [Internet]. 2015 [cited 2018 Mar 19];22(4):176-80. Available from: https://www.revistas.usp.br/actafisiatrica/ article/view/122489/pdf_1

9. Martins AC, Felli VEA. Sintomas musculo-esqueléticos em graduandos de enfermagem. Enferm Foco (Brasília). 2013;4(1):58-62.

10. Kazemi SS, Javanmardi E, Ghazanfari E. Relationship between general health and musculoskeletal disorders among tarbiat modares university students. Int J Musculosk Pain Prev. 2017;2(3):287-91.

11. Kuorinka I, Jonsson B, Kilbom A, Vinterberg H, Biering-Sorensen F, Andersson G, et al.Standardised Nordic questionnaires for the analysis of musculoskeletal symptoms. Appl Ergon. 1987;18(3):233-7. 
12. Barros E, Alexandre NMC. Cross-cultural adaptation of the Nordic musculoskeletal questionnaire. Int Nurs Rev. 2003;50(2):101-13.

13. Associação Brasileira para o Estudo da Obesidade e da Síndrome Metabólica. Diretrizes Brasileiras de Obesidade $2009 / 2010$ [Internet]. Itapevi (SP): AC Farmacêutica; 2009 [citado 2018 abr. 12]. Disponível em: http://www.abeso.org.br/pdf/diretrizes_brasileiras_ obesidade_2009_2010_1.pdf

14. Paixão MS, Tassiano RM, Siqueira GR. Prevalence of musculoskeletal discomfort and associated factors in college students. Rev Bras Promoção Saúde. 2013;26(2):242-50.

15. Hall JE. Tratado de fisiologia médica. Rio de Janeiro: Elsevier; 2017.

16. Vandenberghe L, Ferro CLB. Terapia de grupo embasada em psicoterapia analítica funcional como abordagem terapêutica para dor crônica: possibilidades e perspectivas. Rev Psicol [Internet]. 2005 [citado 2018 jul. 17];7(1):137-51. Disponível em: http://pepsic.bvsalud.org/pdf/ ptp/v7n1/v7n1a11.pdf

17. Haeffner R, Sarquis LMM, Haas GFS, Heck RM, Jardim VMR. Prevalência de lombalgia e fatores associados de uma empresa de agropecuária do sul do Brasil. Rev Bras Med Trab. 2015;13(1):35-42.

18. Ramos AM, Barlem JGT, Lunardi VL, Barlem ELD, Silveira RS, Bordignon SS. Satisfaction with academic experience among undergraduate nursing students. Texto Contexto Enferm [Internet]. 2015 [cited 2018 Mar 19];24(1):187-95. Available from: http://www.scielo.br/pdf/tce/ v24n1/0104-0707-tce-24-01-00187.pdf

19. Viero V, Beck CLC, Coelho APF, Dal Pai D, Freitas PH, Fernandes MNS. Pediatric oncology nursing workers: the use of defensive strategies at work. Esc Anna Nery Rev Enferm [Internet]. 2017 [cited 2018 Mar 19];21(4):1-8. Available from: http://www.scielo.br/pdf/ean/v21n4/14148145-ean-2177-9465-EAN-2017-0058.pdf

20. Smith SM, Sumar B, Dixon KA. Musculoskeletal pain in overweight and obese children. Int J Obes. 2014;38(1):11-5. DOI: http://dx.doi. org/10.1038/ijo.2013.187

21. Marques $\mathrm{AB}$. Associação entre excesso de peso, obesidade, dor músculoesquelética e osteoartrose em cuidados de saúde primários: estudo transversal. Rev Port Med Geral Fam [Internet]. 2017 [citado 2018 mar. 19];33(222-8). Disponível em: http://www.scielo.mec.pt/ $\mathrm{pdf} / \mathrm{rpmgf} / \mathrm{v} 33 \mathrm{n} 3 / \mathrm{v} 33 \mathrm{n} 3 \mathrm{a} 07 . \mathrm{pdf}$

22. Guterres JL, Schmitt FS, Oliveira LC, Simon CDS, Lopes AR. Principais queixas relacionadas ao uso excessivo de dispositivos móveis. Pleiade [Internet]. 2017 [citado mar. 28];11(21):39-45. Disponível em: https://pleiade.uniamerica.br/index.php/pleiade/article/view/333/416

23. Silva Junior WR, Cavalcanti AL. Prevalence of pain and its association with transportation of school supplies in university students. Rev Bras Cineantropom Desempenho Hum [Internet]. 2014 [cited 2018 Mar 19];16(6):680-8. Available from: http://www.scielo.br/pdf/rbcdh/ v16n6/1980-0037-rbcdh-16-06-00680.pdf

24. Vieira AJO, Julião Filho CAB, Firmino RT, Granville-Garcia AF, Menezes VA. Conhecimento de ergonomia e desordens osteomusculares entre estudantes de odontologia. RFO (Passo Fundo) [Internet]. 2014 [citado 2018 mar. 19];19(3):304-10. Disponível em: http://revodonto. bvsalud.org/pdf/rfo/v19n3/a07v19n3.pdf

25. Silva TPD, Araújo WN, Stival MM, Toledo AM, Burke TN, Carregaro RL. Musculoskeletal discomfort, work ability and fatigue in nursing professionals working in a hospital environment. Rev Esc Enferm USP. 2018;52:e03332. DOI: http://dx.doi.org/10.1590/S1980220X2017022903332 